\title{
Evaluation of Distribution and Bioaccumulation of Arsenic by ICP-MS in Tilapia (Oreochromis niloticus) Cultivated in Different Environments
}

\author{
Luciano H. B. Oliveira, ${ }^{a}$ Nathália S. Ferreira, ${ }^{a}$ Andrea Oliveira, ${ }^{b}$ Ana Rita A. Nogueira ${ }^{*, c}$ \\ and Mario H. Gonzalez, $*$,
}

\author{
${ }^{a}$ Departamento de Química e Ciências Ambientais, \\ Instituto de Biociências, Letras e Ciências Exatas (Ibilce), \\ Universidade Estadual Paulista "Júlio de Mesquita Filho" (UNESP), \\ P.O. Box 136, 15054-000 São José do Rio Preto-SP, Brazil
}

${ }^{b}$ Departamento de Química, Universidade Federal do Paraná, 81531-980 Curitiba-PR, Brazil

${ }^{c}$ Embrapa Pecuária Sudeste, 13560-970 São Carlos-SP, Brazil

\begin{abstract}
The concentration of arsenic in tissues of tilapia was evaluated and an estimation of the risks associated with the consumption of this fish was done, taking into account the guidelines established by FAO/WHO. The inductively coupled plasma mass spectrometry (ICP-MS) technique in kinetic energy discrimination (KED) mode was employed and certified reference materials were analyzed with recoveries of 101, 110, and 80\% from NIST 1640a (trace elements in water), NIST 1566b (oyster tissue), and DORM-3 (fish protein). In the consumable portion (the muscle fish tissue), the average concentration found was $0.030 \pm 0.008 \mu \mathrm{g} \mathrm{g}{ }^{-1}$, which is below the arsenic maximum level established by international regulatory agencies. The average concentration found in the viscera (stomach, gills, and liver) was $0.485 \pm 0.225 \mu \mathrm{g} \mathrm{g}^{-1}$, concluding that the viscera had greater capacity for the bioaccumulation of arsenic. From this study was possible to monitor the arsenic element in different tilapia specimens evidencing its accumulation throughout the body of the fish.
\end{abstract}

Keywords: bioaccumulation, arsenic, ICP-MS, KED mode, fish tissues

\section{Introduction}

Aquaculture is the practice of cultivating organisms such as fish and crustaceans in all types of aquatic environments, including lakes, lagoons, rivers, and oceans. ${ }^{1}$ In the last 60 years, the global consumption of fish has doubled due to changes in dietary habits. The search for healthier sources of protein, associated with lower levels of saturated fat, has led to a significant increase in demand for fish and other seafood. ${ }^{2}$

Aquaculture now accounts for half of the fish consumed worldwide, with pisciculture (fish-farming) production almost tripling in volume between 1995 and 2007. ${ }^{3}$ This increase has been partly due to increased consumer demand for omega-3, an essential fatty acid present in fish that is beneficial to cardiovascular health. Fish and other seafood are rich sources of long chain polyunsaturated omega-3 fatty acids (n-3 PUFAs), which are present at concentrations of 10 to 100 times higher than in lipids from terrestrial animals. ${ }^{4}$

*e-mail: ana.nogueira@embrapa.br; gonzalez@ibilce.unesp.br
In the last ten years, consumption has more than doubled in Brazil. Only in 2012 to 2013, consumption in the country grew by almost $25 \%$ exceeding the minimum established by WHO, which is a recommendation of $12 \mathrm{~kg}$ inhabitant ${ }^{-1}$ year $^{-1}$. Currently, the population consumes an average of $14.5 \mathrm{~kg}$ of fish per capita year ${ }^{-1}$. This growth can be explained by improved living conditions and higher disposable incomes, which have increased the demand for healthier foods. ${ }^{5}$

Despite the many health benefits of fish and other seafood, these organisms are liable to exposure to toxic substances naturally present in the water or released due to anthropogenic activities. Examples are toxic metals such as arsenic (As) and mercury (Hg), which can become bioaccumulated through the food chain.

As part of the human diet, fish can be a major source of arsenic ingestion, although a significant fraction of this contaminant is present in fish tissues in the form of organic compounds, such as arsenobetaine (AsB) of low toxicity, which is not metabolized in humans. However, other arsenic species are also present in the fish, such as 
methylated arsenic species (dimethylarsinic acid (DMA) and monomethylarsonic acid (MMA)) that presents moderated toxicity for human healthy. Organoarsenic species also are found in fish such as arsenosugars and arsenolipids and the knowledge about the quantification of these arsenic species is important due to possible biotransformation of these organoarsenic species in potentially toxic arsenic species. The quantification of arsenic at trace concentrations remains a challenge, as reported by Pétursdóttir et al. ${ }^{6,7}$ However, several studies have reported the use of inductively coupled plasma mass spectrometry (ICP-MS), following microwave digestion of samples in a closed vessel, as one of the best techniques to ensure accurate analytical results. ${ }^{8-10}$

The fish selected in the present work for evaluation of arsenic bioaccumulation and toxicity was tilapia (Oreochromis niloticus). This specie, which originates from the Nile basin in Egypt, has become widespread in Brazil because it can adapt to extensive rearing in ponds or intensive fish-farming systems. ${ }^{11}$ Aquatic organisms can bioaccumulate arsenic more efficiently than terrestrial species, either by direct contact or due to feeding on contaminated prey. ${ }^{12}$ The concentrations of trace elements in the muscles and liver of two species of fish (Mullet and Kutum) were analyzed, finding higher concentrations in the liver of the analyzed fishes. ${ }^{13}$ Fish and other aquatic species wich are present at high trophic levels have a greater tendency to concentrate toxic metals in certain parts of the body, hence requiring studies of the levels of toxic elements accumulation. ${ }^{14}$

Attar et al..$^{15}$ evaluated the levels of total arsenic in the muscle tissues of thirteen species of fish in the Arabian Gulf, reporting concentrations in the range $0.16-32.3 \mu \mathrm{g} \mathrm{g}^{-1}$. Liau et al. ${ }^{16}$ found total arsenic concentrations of 12.65 and $3.55 \mu \mathrm{g} \mathrm{g}^{-1}$ in tilapia muscle and viscera, respectively, and suggested that cooking the fish was an easy way to reduce arsenic ingestion. Current Brazilian legislation sets a maximum limit for arsenic in fish of $1 \mathrm{mg} \mathrm{kg}^{-1}$, according to RDC No. 42 of August 29, 2013. ${ }^{17}$

In light of the low limit level for this contaminant, together with the rapid growth in fish sales, the aim of this work was to determine the arsenic contents in tilapia obtained from river and lake fishery sources, and to assess risks to the health of the population using estimates of the amounts of fish consumed.

\section{Experimental}

Instrumentation

The analytical measurements were performed by ICP-MS, using a NexION 300X instrument (PerkinElmer,
Shelton, CT, USA) equipped with a concentric Meinhard nebulizer, a cyclonic spray chamber, and a quartz torch with a quartz injector tube $(2.0 \mathrm{~mm}$ i.d.). The nebulizer gas flow rate, the quadrupole voltages, and the torch alignment were adjusted according to the manufacturer's recommendations, using conventional nebulization. In KED mode, the universal cell technology (UCT) was used with helium at a flow rate that was optimized prior to analysis of the samples. The radiofrequency (RF) power was $1600 \mathrm{~W}$ and the data were obtained in triplicate. The Table 1 provides the instrumental configurations and the data acquisition parameters.

Table 1. Instrumental parameters for ICP-MS analysis

\begin{tabular}{lc}
\hline Radiofrequency power / W & 1600 \\
Plasma gas flow / $\left(\mathrm{L} \mathrm{min}^{-1}\right)$ & 18 \\
Auxiliary gas flow / $\left(\mathrm{L} \mathrm{min}^{-1}\right)$ & 1.2 \\
Nebulizer gas flow / $\left(\mathrm{mL} \mathrm{min}^{-1}\right)$ & 1.0 \\
Sample uptake rate / $\left(\mathrm{mL} \mathrm{min}^{-1}\right)$ & 0.7 \\
\hline $\mathrm{KED}^{\mathrm{a}}$ mode & \\
\hline Entrance lens / V & -3.00 \\
Exit lens / V & -32.00 \\
CRO / V & -15.00 \\
$\mathrm{QRO}^{\mathrm{c}} / \mathrm{V}$ & -15.00 \\
\hline Method parameters & 50 \\
\hline Sweeps/reading & 1 \\
Reading/replicates & 3 \\
Replicates & 25 \\
Dwell times / ms & $\mathrm{He}$ \\
Gas channel & 0.25 \\
RPq / V & $0.2-3.0$ \\
He flow rate / $\left(\mathrm{mL} \mathrm{min}{ }^{-1}\right)$ & $0.1-15.0$ \\
Calibration range / $\left(\mu \mathrm{g} \mathrm{L} \mathrm{L}^{-1}\right)$ & \\
\hline
\end{tabular}

${ }^{a}$ KED: kinetic energy discrimination; ${ }^{\mathrm{b}} \mathrm{CRO}$ : cell rod offset; ${ }^{\mathrm{C}} \mathrm{QRO}$ : quadrupole rod offset; ${ }^{\mathrm{d}} \mathrm{RPq}$ : quadrupole dynamic bandpass tuning parameters.

The evaluation of UCT was done employing certified reference materials with matrices similar to those of the samples, with the ICP-MS operated in standard and kinetic energy discrimination (KED) modes. In the standard instrument operation mode (without UCT), two mathematical equations were tested for the correction of errors due to potential interference present in the samples, in addition to operation without correction. In KED mode, five collision cell helium flow rates $\left(0.2-3.0 \mathrm{~mL} \mathrm{~min}^{-1}\right)$ were tested in order to observe the degree of correction and the loss of sensitivity caused by operation of the instrument in this mode. Calibration curves were constructed for all the conditions tested. 
The fish tissue samples were triturated using a cryogenic mill (MA775, Marconi, Piracicaba, Brazil) with capacity for up to four transparent polycarbonate cylinders, operated at $20 \mathrm{~Hz}$. The digestions were carried out in a microwave oven (Multiwave 3000, Anton Paar GmbH, Graz, Austria), fitted with a rotor (model 16MF100) with capacity for up to 16 digestion flasks. A reference flask equipped with a temperature and pressure sensor was included in all the digestions.

The glassware, flasks, test tubes, pipette tips, and other materials used in the experiments were previously decontaminated and demineralized for $48 \mathrm{~h}$ in acid baths containing $10 \%\left(\mathrm{v} \mathrm{v}^{-1}\right) \mathrm{HNO}_{3}$, followed by washing three times with ultrapure deionized water. The $18.2 \mathrm{M} \Omega \mathrm{cm}$ deionized water employed to prepare the reagents and standards was obtained from a Milli-Q system (Millipore, USA). The microwave digestions used sub-distilled concentrated $\mathrm{HNO}_{3}$ (Sigma-Aldrich, St Louis, MO, USA) $65 \% \mathrm{~m} \mathrm{~m}^{-1}$ and $\mathrm{H}_{2} \mathrm{O}_{2}$ (Sigma-Aldrich, St Louis, MO, USA) $30 \% \mathrm{~m} \mathrm{v}^{-1}$. The cryogenic mill was operated using liquid nitrogen $(99.999 \%$, Nitrogen Comércio de Nitrogênio Líquido Ltda., Ribeirão Preto, Brazil).

The standard arsenic solutions used to construct the analytical curves and for calibration during the ICP-MS analyses were prepared from intermediate dilutions of standard $998 \pm 2 \mathrm{mg} \mathrm{L}^{-1}$ solution of arsenic (Fluka). Argon (99.999\%) and helium (99.999\%) (White Martins, Sertãozinho, Brazil) were used as the plasma generator/nebulizer/auxiliary gas and the collision gas, respectively.

The accuracy of the method was evaluated using the certified reference materials NIST 1640a (trace elements in water), NIST 1566a (oyster tissue), and NRCC DORM-3 (fish protein), with certified total arsenic values of $8.075 \pm 0.070,7.65 \pm 0.65$, and $6.88 \pm 0.3 \mu \mathrm{g} \mathrm{g}^{-1}$, respectively.

\section{Samples and sample preparation}

The tilapias were collected during July-August 2015. According to paragraph 2 of Article 3 of Normative Instruction No. 03 (September 1, 2014), which regulates the collection and capture of species for scientific or didactic purposes (Environmental Ministry, 2014), ${ }^{5}$ the regulation does not apply to the collection and transport of biological materials derived from domesticated or cultivated species, or non-indigenous wild species, except for research conducted in federal conservation units in the public domain, so no special authorization was required to obtain the tilapia.

Five specimens were collected at each of three locations in the northwest of São Paulo State: a fishing lake near São
José do Rio Preto City ( $20^{\circ} 45^{\prime}$ '49” S; 49 $19^{\circ}$ ' 16” W); a cultivation system using net cages in the Tiete River near Buritama City (21 7 ' 7.58" S; 50 $\left.10^{\circ} 29.81^{\prime \prime} \mathrm{W}\right)$; and a fish merchant in the city of Votuporanga $\left(20^{\circ} 25^{\prime} 1.10^{\prime \prime} \mathrm{S}\right.$; $49^{\circ} 58^{\prime} 31.48^{\prime \prime} \mathrm{W}$ ). Water samples were also collected and stored in a refrigerator at $-5^{\circ} \mathrm{C}$ for subsequent analysis of total arsenic.

Following established procedures to ensure the quality of results and avoid possible problems of contamination, the collected fish were placed in hermetically sealed plastic bags, in an insulated box containing ice that had been previously demineralized, and were promptly retrieved to the laboratory. They were washed with deionized water, measured, and weighed, followed by removal of the main organs (gills, stomach, and liver) using stainless steel surgical instruments. Portions of muscle tissue were also removed. The samples of each type of tissue were pooled according to the collection site, totaling 12 biological samples (4 from each location). All the samples were lyophilized for $72 \mathrm{~h}$ in glass flasks, under vacuum at $-195{ }^{\circ} \mathrm{C}$, and then stored in a desiccator for subsequent analysis. The muscle tissues required a previous step using a ceramic knife to reduce the size of the pieces. The grinding program included $1 \mathrm{~min}$ for the freezing step and 3 min of grinding.

Approximately $200 \mathrm{mg}$ of each sample was digested using $6.0 \mathrm{~mL}$ of $\mathrm{HNO}_{3}\left(7.0 \mathrm{~mol} \mathrm{~L}^{-1}\right)$ and $2.0 \mathrm{~mL}$ of $\mathrm{H}_{2} \mathrm{O}_{2}\left(30 \% \mathrm{~m} \mathrm{v}^{-1}\right)$ in closed PFA flasks. The temperature and pressure were monitored in all the digestions. The digestions were performed in triplicate using a heating program consisting of two steps with applied power of $1100 \mathrm{~W}$, temperature of $200{ }^{\circ} \mathrm{C}$, and hold time of $20 \mathrm{~min}$, together with a final $10 \mathrm{~min}$ cooling step. After digestion, the samples and blanks were quantitatively transferred to $30 \mathrm{~mL}$ polypropylene flasks and the volumes were adjusted with ultrapure water. The entire process was performed in triplicate, including the analytical blank solutions.

\section{Estimation of arsenic intake}

The estimated daily or weekly intake of arsenic was calculated based on the average consumption of fresh fish by the Brazilian population, provided by the Ministry of Fisheries and Aquaculture, with a value of $14.50 \mathrm{~kg}$ $\left(39.7 \mathrm{~g} \mathrm{day}^{-1}\right)$ per person for the year 2013. This estimate could then be used to assess the risks associated with chronic ingestion of arsenic, which can cause skin lesions, cardiovascular complications, and cancers.

In this work, the estimated daily intake of arsenic was calculated based on the average body weights of the 
Brazilian population aged from 18 to 65 years, which are $69 \mathrm{~kg}$ (males) and $60 \mathrm{~kg}$ (females), according to Brazilian Institute of Geography and Statistics, IBGE. ${ }^{18}$ The calculation was performed as shown in equation 1 , where $\mathrm{ID}_{\mathrm{As}}$ is the daily intake of arsenic ( $\mu \mathrm{g} \mathrm{kg}^{-1}$ body weight per day), $\mathrm{C}_{\mathrm{p}}$ is the consumption of tilapia by the Brazilian population $\left(\mathrm{g} \mathrm{day}^{-1}\right), \mathrm{C}_{\mathrm{t}}$ is the concentration of total As in the fish muscle tissue $\left(\mu \mathrm{g} \mathrm{kg}^{-1}\right)$, and $\mathrm{P}_{\mathrm{c}}$ is the average male or female body weight of the Brazilian population $(\mathrm{kg})$.

$\mathrm{ID}_{\mathrm{As}}=\frac{\mathrm{C}_{\mathrm{p}} \times \mathrm{C}_{\mathrm{t}}}{\mathrm{P}_{\mathrm{c}}} \times 10^{-3}$

\section{Analytical performance}

The analytical methodology employed in this work included the use of parameters to evaluate the quality of the results. These parameters are indispensable tools for the validation of analytical methods. In accordance with National Institute of Metrology Quality and Technology (INMETRO/2006) ${ }^{19}$ and Brazilian Health Regulatory Agency (ANVISA/2003), ${ }^{20}$ method validation involves evidence that the method meets the needs of the analytical application and can provide reliable results.

Method validation is one of the necessary measures that a laboratory must implement to obtain reliable analytical data. ${ }^{21}$ The procedure should provide details of selectivity, linearity, working range and confidence interval, precision, limits of detection (LOD) and quantification (LOQ), recovery, and accuracy as recommended by ANVISA. ${ }^{20}$ In the present work, the data were treated considering these parameters, and descriptive statistics (means, standard deviations, and ranges) were obtained using Excel software. The certified reference materials (CRMs) were used to confirm the accuracy of the method.

\section{Results and Discussion}

\section{KED optimization}

Firstly, the ICP-MS method was optimized by determining total arsenic in the three certified reference materials using the standard and KED operating modes to identify the conditions that provided the most accurate results. In the standard operating mode, without the use of UCT, two mathematical equations were tested for the correction of potential interferences. In the KED mode, five collision cell helium flow rates were tested (2A-2E), observing the degree of correction and the loss of sensitivity. Equations 2 and 3 were employed for the correction in standard mode.

$$
\begin{aligned}
& \mathrm{I}\left(\mathrm{As}^{75}\right)=-3.127 \times \text { mass } 77 \\
& \mathrm{I}\left(\mathrm{As}^{75}\right)=-3.127 \times(\operatorname{mass} 77-0.874 \times \text { mass } 82)
\end{aligned}
$$

These equations are provided by the software of the equipment and take into account the correction for the major ${ }^{75} \mathrm{As}$ polyatomic interference, ${ }^{40} \mathrm{Ar}{ }^{35} \mathrm{Cl}$. The net signal of ${ }^{75} \mathrm{As}$ without interferences is represented by I $\left(\mathrm{As}^{75}\right)$. The mass 77 refers to the polyatomic ${ }^{40} \mathrm{Ar}{ }^{37} \mathrm{Cl}$ and the mass 82 refers to ${ }^{82} \mathrm{Se}$, which is used to correct the interference at $\mathrm{m} / \mathrm{z} 77$. Analytical curves were constructed for the different conditions tested, and the linearity was evaluated using the linear correlation coefficients. The curves employed eight concentrations of arsenic (0.1-15.0 $\left.\mu \mathrm{g} \mathrm{L}^{-1}\right)$ in $1 \%\left(\mathrm{v} \mathrm{v}^{-1}\right)$ of $\mathrm{HNO}_{3}$ solution. In KED mode, the signal intensity was lower than for the standard mode and decreased with increasing gas flow rate, due to a greater number of collisions in the universal cell. The statistical parameters of the analytical curves are shown in Table 2, with the decreasing angular coefficients reflecting the loss of sensitivity that occurred at higher helium gas flow rates. Despite this loss of sensitivity, operation in KED mode provided low limits of detection and quantification, which were similar to the LOD and LOQ values obtained in the standard operation mode.

The limits of detection and quantification were calculated based on 3 and 10 times of standard deviation of 10 measurements of the analytical blank (intensity measurements), respectively, and results from different conditions tested were statistically different from each other $(p<0.05) .{ }^{20}$ Analysis of the certified reference materials was used to determine the best ICP-MS operating conditions for the determination of arsenic in the studied samples. Figure 1 shows the recoveries (\%) and relative standard deviations (RSD) obtained for each condition tested, achieved to the certified samples. It can be seen that condition (2D) (helium gas flow rate of $2.0 \mathrm{~mL} \mathrm{~min}^{-1}$ in KED mode) provided the most accurate results, which were within the certified ranges. The condition $2 \mathrm{D}$ is a commitment condition established for different certified materials analyzed in the ICP-MS. In fact, the standard mode did not produce satisfactory results, even with the use of the equations for interference correction.

\section{Total arsenic distribution in the specimens}

After optimization of the instrumental parameters, analyses were made of tissues of tilapia (muscle, gills, liver, and stomach) from the three collection sites. The measurements were performed in triplicate. Resulting RSD values for all concentrations determined were below $20 \%$. The muscle tissue was considered the part 
Table 2. Performance parameters of different methods of detection by ICP-MS

\begin{tabular}{lccccc}
\hline Mode $^{\mathrm{a}}$ & $\begin{array}{c}\text { He flow rate / } \\
\left(\mathrm{mL} \mathrm{min}^{-1}\right)\end{array}$ & $\begin{array}{c}\text { Angular coefficients } \\
(\text { slope })\end{array}$ & $\mathrm{R}^{2 \mathrm{~b}}$ & $\begin{array}{c}\text { LOD / } \\
\left(\mu \mathrm{g} \mathrm{L}^{-1}\right)\end{array}$ & $\begin{array}{c}\text { LOQ / } \\
\left(\mu \mathrm{g} \mathrm{L}^{-1}\right)\end{array}$ \\
\hline $1 \mathrm{~A}$ & - & 4750.0 & 0.9991 & 0.022 & 0.075 \\
1B & - & 4772.7 & 0.9992 & 0.029 & 0.096 \\
1C & - & 4718.9 & 0.9986 & 0.026 & 0.088 \\
2A & 0.2 & 4763.2 & 0.9997 & 0.017 & 0.058 \\
2B & 0.5 & 3167.0 & 0.9995 & 0.007 & 0.025 \\
2C & 1.0 & 1429.7 & 0.9990 & 0.013 & 0.042 \\
2D & 2.0 & 195.2 & 0.9981 & 0.023 & 0.075 \\
2E & 3.0 & 17.2 & 0.9961 & 0.062 & 0.208 \\
\hline
\end{tabular}

${ }^{\mathrm{a}} 1$ : standard condition of ICP-MS, where 1A: without using the correction equation, 1B and 1C: employing correction equations; 2 : KED condition, where

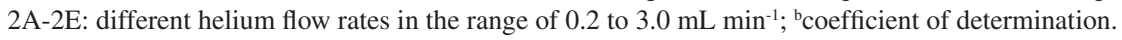

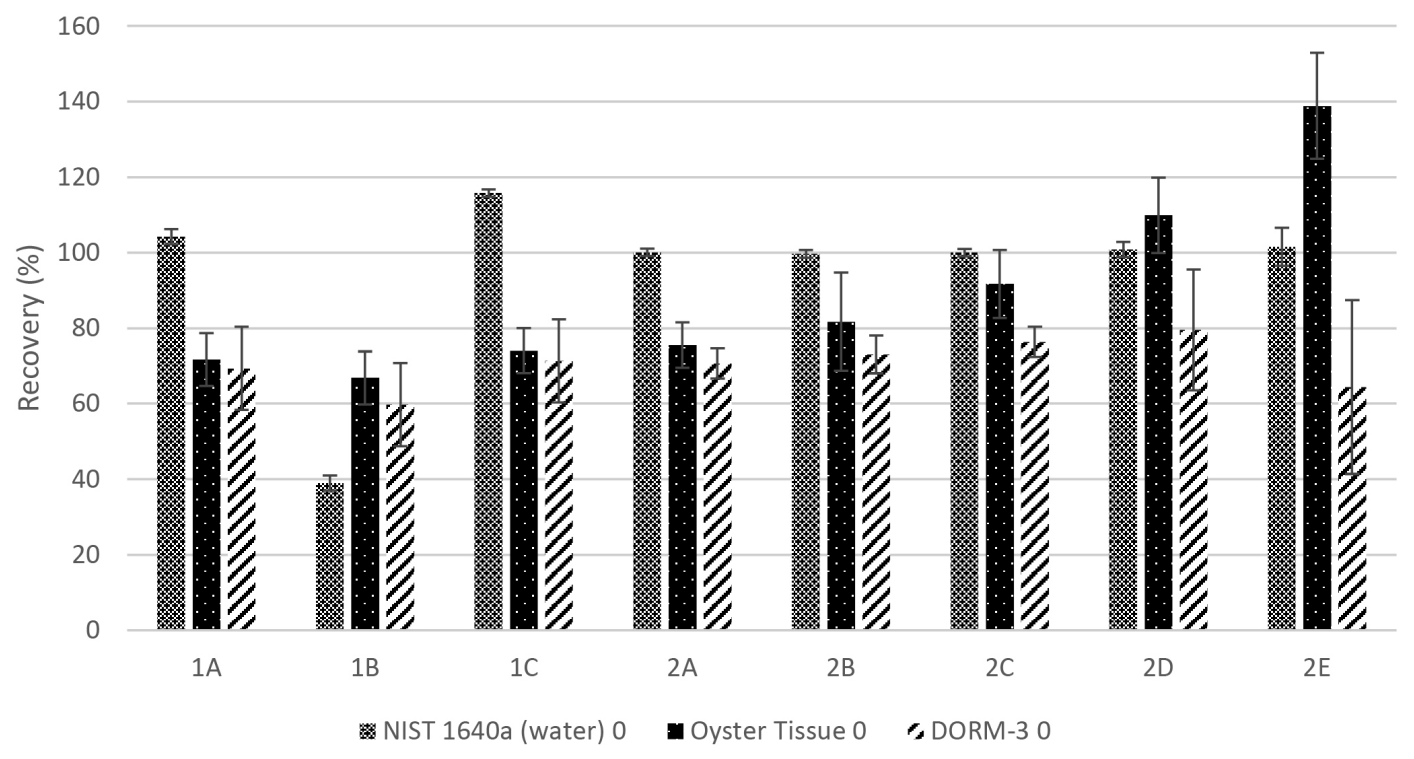

Figure 1. Recovery percentage of different methods applied in the analysis of CRM's.

consumed by humans. Table 3 shows the total arsenic concentrations values found in analyzed tissues and the arsenic concentration profile obtained for the analyzed samples.

Regarding the collection sites (Tiete River, fishing lake and market fish), there was no significant variation $(p>0.05)$ between the determined As concentrations. Bioabsorption is the term used to describe the process by which a substance penetrates into the body of an aquatic organism..$^{22}$ The mechanisms of arsenic bioabsorption in tilapia remain poorly understood, due to the different ways in which arsenic is accumulated by the specimens, as well as the variable concentrations and chemical forms of the element present in the environment. Here, the gills showed relatively low arsenic levels, compared to the other organs analyzed, with the exception of the fish obtained from
Table 3. Total concentration of arsenic determined by ICP-MS in muscle, gill, liver and stomach of analyzed samples $(n=3)$

\begin{tabular}{lccc}
\hline \multirow{2}{*}{ Specimen/water } & \multicolumn{2}{c}{ Total arsenic in specific specimens $\pm \mathrm{SD} /\left(\mu \mathrm{g} \mathrm{g}^{-1}\right)$} \\
\cline { 2 - 4 } & Tiete River & Fishing lake & Market fish \\
\hline Muscle & $0.021 \pm 0.001$ & $0.038 \pm 0.006$ & $0.031 \pm 0.004$ \\
Stomach & $0.052 \pm 0.009$ & $1.170 \pm 0.046$ & $0.034 \pm 0.002$ \\
Liver & $0.032 \pm 0.003$ & $0.051 \pm 0.007$ & $0.029 \pm 0.002$ \\
Gill & $0.016 \pm 0.001$ & $0.039 \pm 0.001$ & $0.031 \pm 0.002$ \\
Water & $0.337 \pm 0.001$ & $0.221 \pm 0.012$ & $0.234 \pm 0.029$ \\
\hline
\end{tabular}

SD: standard deviation.

the market, where the arsenic concentration in the gills were similar to those in the liver. The gills are complex multifunctional organs whose roles include ion transport, 
gas exchange, and excretion of waste. The gills provide the primary route for absorption of metals, potentially leading to acute toxicity in fish. ${ }^{23}$

It can be observed that the collected fish had a small difference $(p>0.05)$ in their sizes in the following decreasing order: Tiete River $(738.2 \pm 113.2 \mathrm{~g})>$ market fish $(871.8 \pm 129.6 \mathrm{~g})>$ fishing lake $(633.8 \pm 138.7 \mathrm{~g})$. The arsenic concentration levels found in market fish are similar among all specimens samples of the fish analyzed. However, the highest arsenic concentration value was obtained for the stomach samples from fishes of the fishing lake, in comparison with other analyzed specimens, which indicates that the accumulation of arsenic is possibly not similar, considering the different organs tissues evaluated. However, these observations are being further studied to check whether different organs and their biological functions can really influence on the distribution and accumulation of arsenic content in fishes of the same species.

Tsai et al..$^{24}$ studied the toxic kinetics in tilapia exposed to copper, finding the lowest concentrations in the gills and muscles, in agreement with the results obtained in the present study. The same work evaluated the rates of elimination of the metal from tilapia tissues, with the fastest elimination obtained for the muscle tissue. Here, the arsenic concentrations in the muscle tissues of the tilapia ranged from 0.021 to $0.038 \mu \mathrm{g} \mathrm{g}^{-1}$, comparable to the values reported by Wu et al. ${ }^{10}$ who found arsenic concentrations in the range 0.014-0.037 $\mathrm{\mu g} \mathrm{g}^{-1}$ in the muscle tissues of fish obtained in different cities in China.

The concentrations of arsenic in the muscles and gills were similar, especially for the fish obtained from the fishing lake and the market, with values of 0.038-0.039 and $0.031 \mu \mathrm{g} \mathrm{g}^{-1}$, respectively, while concentrations of $0.016-0.021 \mu \mathrm{g} \mathrm{g}^{-1}$ were obtained for fish from the Tiete River. Previous studies have found that the bioaccumulation of arsenic by tilapia is directly proportional to the concentration of the element in the water. ${ }^{16,25}$ The concentrations of As found in the water samples were in the range $0.221-0.337 \mu \mathrm{g} \mathrm{L}^{-1}$ (no significant difference between them, $p>0.05$ ), which could explain the similarity of the concentrations obtained in the gills.

The As concentrations in the liver were similar to those in the gill and muscle tissues for the fish from the market and Tiete River, with values of 0.029 and $0.032 \mu \mathrm{g} \mathrm{g}^{-1}$, respectively, while a higher value was found for the fish from the fishing lake $\left(0.051 \mu \mathrm{g} \mathrm{g}^{-1}\right)$. The liver specimens of fish are commonly used as environmental indicators of water pollution. The liver plays important roles in the storage, redistribution, detoxification, and processing of contaminants, and acts as an active site for pathological effects induced by pollutants. ${ }^{26}$ The observed differences in the values obtained for the livers of fish from different collection sites could be explained by the differences in fish size, because despite having the same length, the body weights differed. Al-Yousuf et al. ${ }^{27}$ reported that metal concentrations generally decreased with increasing size of the fish. This statement provides an explanation for the higher arsenic levels observed for the tilapia from the fishing lake, which had lower body weights, compared to the fish from the other two collection sites.

In all cases, the highest arsenic concentrations were found in the stomach tissue, with arsenic concentration values in the range $0.034-1.170 \mu \mathrm{g} \mathrm{g}^{-1}$. The order of concentration of As for fish from the different locations were as follows: stomach $>$ liver $>$ muscle $>$ gills (Tiete River); stomach $>$ liver $>$ muscle $\approx$ gills (fishing lake); stomach $>$ muscle $\approx$ gills $>$ liver (market). Overall, this order is similar to the findings of Liau et al., ${ }^{16}$ who reported the following order of bioaccumulation in the tissues: stomach $>$ liver $\approx$ gills $>$ muscle.

The stomach specimens of tilapia collected in the fishing lake were the only samples that solid material remained at the base of the flask after microwave digestion, even following repetitions of the sample treatment procedure. These samples contained elevated levels of arsenic $\left(1.170 \mu \mathrm{g} \mathrm{g}^{-1}\right)$ compared to the fish from the other locations. Nonetheless, it can be speculated that the high concentration of As resulted from the system used to rear the fish. The tilapias in the tank from which the fish were removed and transferred to the lake (as well as those in the lake) were fed a variety of natural or synthetic foods, which could have influenced the findings. Further studies are needed to investigate the effects of the food and the sediment to which the fish are exposed.

\section{Estimation of arsenic intake}

In 1989, the Joint Food and Agriculture Organization of the United Nations/World Health Organization (FAO/WHO) Expert Committee on Food Additives (JECFA) established a provisional tolerable weekly intake (PTWI) of $15 \mu \mathrm{g} \mathrm{As} \mathrm{kg}^{-1}$ body weight. ${ }^{28}$ However, the European Food Safety Authority (EFSA) Panel on Contaminants in the Food Chain (CONTAM Panel) determined that this estimate was no longer appropriate, because data showed that inorganic arsenic caused cancer of the lung and bladder at levels previously considered safe..$^{29,30}$

The CONTAM Panel established reference intakes (benchmark dose lower limits, BMDLs) ranging from 0.3 to $8 \mu \mathrm{g} \mathrm{kg}^{-1}$ body weight per day as indicators to characterize 


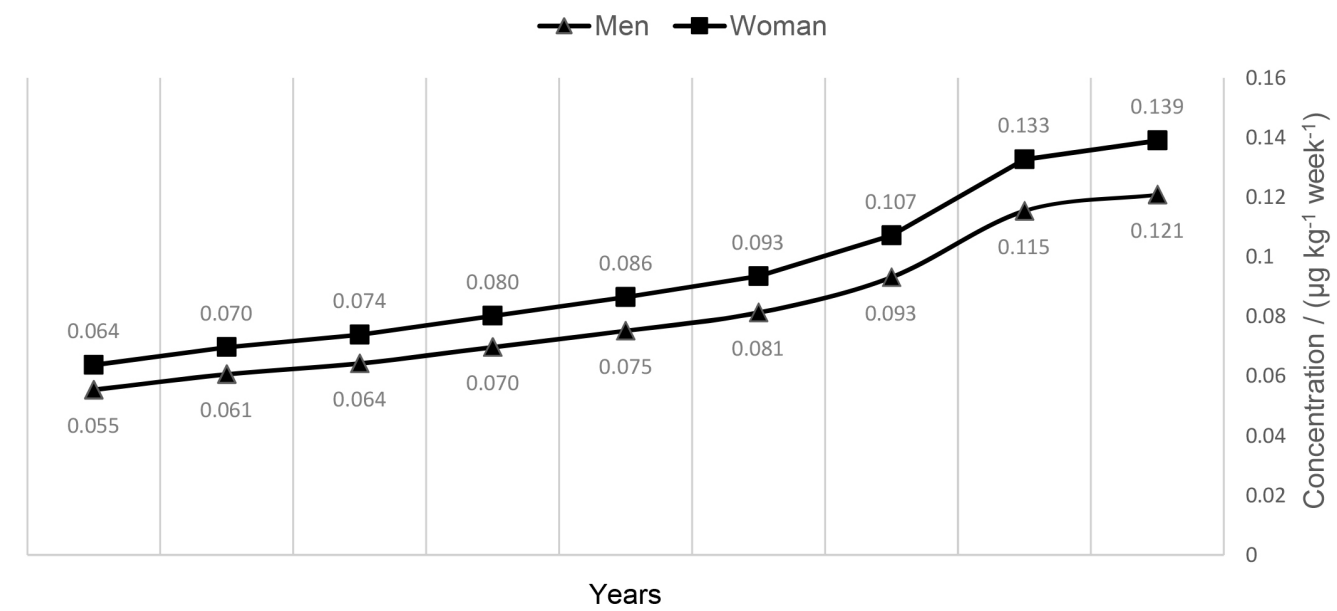

Figure 2. Estimated arsenic weekly intake assuming the growth in seafood consumption by the Brazilian population.

the risks associated with inorganic arsenic. These values correspond to the $95 \%$ of confidence limit of the BMDL that causes $1 \%$ additional risk $\left(\mathrm{BMDL}_{01}\right)$ of skin, bladder, and lung cancer. Based on epidemiological studies, JECFA recommended more restrictive reference values of $2-7 \mu \mathrm{g} \mathrm{kg}^{-1}$ body weight per day, corresponding to a $0.5 \%$ increase in the possible incidence of lung cancer $\left(\mathrm{BMDL}_{05}\right){ }^{29}$

Fish consumption in Brazil has increased over the years, with the latest data released by the MAPA ${ }^{31}$ indicating an increase of 5\% between the years 2012 and 2013, reaching $14.5 \mathrm{~kg}$ per person per year. The arsenic intakes of the population were estimated using this value together with average body weights of 69 and $60 \mathrm{~kg}$, respectively, for adult men and women aged between 18 and 65 years (data from IBGE). ${ }^{18}$ It was assumed that the muscle tissue was the part of the fish consumed, with an average overall total arsenic concentration of $0.030 \pm 0.008 \mu \mathrm{g} \mathrm{g}^{-1}$. Based on the data obtained, the estimated weekly intakes of arsenic by the Brazilian population were 0.121 and $0.139 \mu \mathrm{g} \mathrm{kg}^{-1}$ body weight week ${ }^{-1}$ for men and women, respectively. These levels are well below the provisional tolerable weekly intake (PTWI) guideline value $\left(15 \mu \mathrm{g} \mathrm{kg}^{-1}\right.$ body weight) established in 1989 by the Joint Food and Agriculture Organization of the United Nations/World Health Organization (FAO/WHO) Expert Committee on Food Additives (JECFA). Figure 2 shows a graph of the estimated weekly intake of arsenic, taking into account the growth in consumption of fish by Brazilian population.

The estimated daily intakes of arsenic were 0.017 and $0.020 \mu \mathrm{g} \mathrm{kg}^{-1}$ body weight $\mathrm{day}^{-1}$ for men and women, respectively. These values are well below the maximum levels adopted by the CONTAM Panel (0.3-8.0 $\mu \mathrm{g} \mathrm{kg}^{-1}$ body weight $\mathrm{day}^{-1}$ ) and JECFA (2.0-7.0 $\mu \mathrm{g} \mathrm{kg}^{-1}$ body weight day-1) to indicate a possible risk of incidence of cancer. It should be noted that these safety levels consider concentrations of inorganic arsenic, which is much more toxic to humans, compared to organic arsenic compounds. In the present work, it is considered the total arsenic concentration.

It can be seen from Figure 2 that arsenic intake has increased over the last decade. However, the arsenic present in aquatic organisms is mainly in the form of organic compounds that are excreted by the human body, indicating that fish can be safely consumed at the levels currently estimated for the Brazilian population. Moreover, it should be emphasized that the study conducted only considered consumption of tilapia by the population. Other types of fish could be consumed, contributing to different levels of arsenic intake.

\section{Conclusions}

The ICP-MS technique provided an accurate determination of arsenic at trace levels in biological matrices, such as tilapia tissues after a sample treatment in acidic conditions.

To obtain a better understanding of the results for arsenic content in different organs of the tilapia fish it is important to consider some aspects, such as: feeding habits, the time contact between the fish and the contaminated environments, and the characteristics of the sediment.

It could be concluded that the growth in the fish consumption by Brazilian population has resulted in increased arsenic intake. However, the observed arsenic levels were below all the guideline values established by international agencies. Taking into account that most of arsenic specie present in fish is in the organic form, such as arsenobetaine, which presents a relatively low risk to the health. In fact, generally the fish are eviscerated before 
consumption, suggesting that the associated risks to human health are minimal.

\section{Acknowledgments}

The authors are grateful to São Paulo Research Foundation (FAPESP, Process 2015/08873-9), Fundação de Apoio à Pesquisa e Extensão de São José do Rio Preto (FAPERP) for research grant 74/2015, Coordenação de Aperfeiçoamento de Pessoal de Nível Superior (CAPES, 33004153077P8) for fellowship provided to L. H. B. O., and FAPESP 2016/05079-2 for fellowship provided to N. S. F.

\section{References}

1. Jhingran, V. G.; Introduction to Aquaculture, United Nations Development Programme, Food and Agriculture Organization of the United Nations, Nigerian Institute for Oceanography and Marine Research: Port Harcourt, 1987. Available at http:// www.fao.org/docrep/field/003/ac169e/ac169e00.htm, accessed in October 2016.

2. Figueiredo, J.; Alberto, C.; Valente, J.; Saboya, A.; Cultivo de TilápiasnoBrasil: Origense CenárioAtual,2008.Availableathttp:// www.sober.org.br/palestra/9/178.pdf, accessed in May 2017.

3. https://www.sciencedaily.com/releases/2009/09/090907162320. htm, accessed in May 2017.

4. United Nations Environment Programme, Division of Technology, Industry and Economics (DTIE) Chemicals Branch; WHO Department of Food Safety, Zoonoses and Foodborne Diseases; Guidance for Identifying Populations at Risk from Mercury Exposure; Inter-Organisation Programme for the Sound Management of Chemicals (IOMC): Geneva, Switzerland, 2008. Available at http://www.who.int/foodsafety/publications/chem/ mercuryexposure.pdf?ua=1, accessed in May 2017.

5. http://www.icmbio.gov.br/sisbio/images/stories/ instrucoes_normativas/INSTRU\%C3\%87\%C3\%830_ NORMATIVA_ICMBio_N\%C2\%BA_3_DE_2014__com_ retifica\%C3\%A7\%C3\%A3o_do_DOU18062015.pdf, accessed in May 2017.

6. Pétursdóttir, A. H.; Gunnlaungsdóttir, H.; Krupp, E. M.; Feldmann, J.; Food Chem. 2014, 150, 353.

7. Pétursdóttir, A. H.; Sloth, J. J.; Feldmann, J.; Anal. Bioanal. Chem. 2015, 407, 8385.

8. Fontcuberta, M.; Calderon, J.; Villabí, J. R.; Centrich, F.; Portaña, S.; Espelt, A.; Duran, J.; Nebot, M.; J. Agric. Food Chem. 2011, 59, 10013.

9. Pétursdóttir, A. H.; Gunnlaugsdóttir, H.; Jörundsdóttir, H.; Mestrot, A.; Krupp, E. M.; Feldmann, J.; Anal. Bioanal. Chem. 2012, 8, 2185.

10. Wu, X.; Gao, M.; Wang, L.; Ecotoxicol. Environ. Saf. 2014, $102,168$.
11. Neves, R. C.; Moraes, P. M.; Ferrari, J. E.; Lima, P. M.; Santos, F. A.; de Castro, G. R.; Barros, M. M.; Padilha, P. M.; Food Addit. Contam., Part B 2011, 4, 238.

12. Barra, C. M.; Santelli, R. E.; Abrão, J. J.; de la Guardia, M.; Quim. Nova 2000, 23, 58.

13. Agah, H.; Peyman, E.; Fereydon, O.; Reza, F. S. M.; J. Persian Gulf (Marine Sci.) 2010, 1, 55.

14. Taweel, A.; Shuaimi, M.; Ahmad, A. K.; Ecotoxicol. Environ. Saf. 2013, 93, 45.

15. Attar, K. M.; el-Faer, M. Z.; Rawdah, T. N.; Tawabini, B. S.; Mar. Pollut. Bull. 1992, 24, 94.

16. Liau, C. M.; Chen, B. C.; Singh, S.; Lin, M. C.; Liu, C. W.; Han, B. C.; Environ. Toxicol. 2003, 18, 252.

17. Agência Nacional de Vigilância Sanitária (ANVISA); Resolução - RDC No. 42, de 29 de agosto de 2013; Dispõe sobre o Regulamento Técnico MERCOSUL sobre Limites Máximos de Contaminantes Inorgânicos em Alimentos; DOU No. 168, 30 de agosto de 2013, Brasil. Available at http://portal.anvisa.gov.br/documents/33916/393845/ RDC\%2Bn\%C2\%BA\%2B42_2013_final.pdf/eec629cf-8d17422b-a362-366b275c1a00?version=1.0, accessed in May 2017.

18. Brazilian Institute of Geography and Statistics (IBGE); Pesquisa de Orçamentos Familiares (POF) 2015-2016; IBGE: Rio de Janeiro, 2014. Available at https://www.ibge.gov.br/home/ estatistica/indicadores/sipd/decimo_quinto_forum/15_forum_ SIPD_POF_2015_2016.pdf, accessed in May 2017.

19. Coordenação Geral de Acreditação; DOQ-CGCRE-008; Orientação sobre Validação de Métodos Analíticos: Documento de Caráter Orientativo; Revisão 05 - Agosto 2016; Instituto Nacional de Metrologia, Qualidade e Tecnologia (INMETRO), Brasil, 2016. Available at http://www.inmetro.gov.br/Sidoq/ Arquivos/Cgcre/DOQ/DOQ-Cgcre-8_04.pdf, accessed in May 2017.

20. Agência Nacional de Vigilância Sanitária (ANVISA); Resolução - RE No. 899, de 29 de maio de 2003; Guia para Validação de Métodos Analíticos e Bioanalíticos; DOU, 02 de junho de 2003, Brasilia, Brasil.

21. Thompson, M.; Ellison, S. L. R.; Wood, R.; Pure Appl. Chem. 2002, 74, 835 .

22. Chen, B.; Liao, C.; Aquaculture 2004, 242, 365.

23. Licata, P.; Trombetta, D.; Cristani, M.; Naccari, C.; Martino, D.; Caló, M.; Naccari, F.; Environ. Monit. Assess. 2005, 107, 239.

24. Tsai, J.; Ju, Y.; Huang, Y.; Deng, Y.; Chen, W.; Wu, C.; Liao, C.; Environ. Sci. Pollut. Res. 2012, 20, 3771.

25. Alvarado, N. E.; Quesada, I.; Hylland, K.; Soto, M.; Aquat. Toxicol. 2006, 77, 64.

26. Akan, J. C.; Salwa, M.; Yikala, B. S.; Chellube, Z. M.; Br. J. Appl. Sci. Technol. 2012, 2, 311.

27. Al-Yousuf, M. H.; El-Shahawi, M. S.; Al-Ghais, S. M.; Sci. Total Environ. 2000, 256, 87. 
28. Food and Agriculture Organization of the United Nations (FAO/ WHO); Dietary Exposure Assessment of Chemicals in Food; World Health Organization: Maryland, USA, 2005. Available at http:// apps.who.int/iris/bitstream/10665/44027/1/9789241597470_ eng.pdf, accessed in May 2017.

29. EFSA Panel on Contaminants in the Food Chain (CONTAM); EFSA J. 2009, 7, 1351.

30. European Food Safety Authority (EFSA); EFSA J. 2014, 12, 3597.
31. Ministry of Agriculture Livestock and Food Supply (MAPA); Consumo de Pescado no Brasil Aumenta 23,7\% em Dois Anos, 2013. Available at http://www.brasil.gov.br/economiae-emprego/2013/10/consumo-de-pescado-no-brasil-aumenta23-7-em-dois-anos, accessed in June 2017.

Submitted: March 24, 2017

Published online: June 5, 2017 